\title{
СМЕРТНАЯ КАЗНЬ: БЫТЬ ИЛИ НЕ БЫТЬ, ВОТ В ЧЕМ ВОПРОС
}

\author{
(c) 2021 Зайцева Елизавета Евгеньевна \\ студент-магистрант \\ Юридическая Школа ДВФУ, Россия, Владивосток \\ E-mail: zalizaveta98@mail.ru \\ (C) 2021 Баранова Вероника Алексеевна \\ студент-магистрант \\ Юридическая Школа ДВФУ, Россия, Владивосток \\ E-mail:nikazlaya97@mail.ru \\ (c) 2021 Кешишян Александра Вагаршаковна \\ студент-магистрант \\ Юридическая Школа ДВФУ, Россия, Владивосток \\ E-mail: alekasndrak@mail.ru
}

Статья посвящена анализу нормативно-правового регулирования запрета на применение смертной казни в Российской Федерации, рассмотрены различные точки зрения авторов и позиции как «за» смертную казнь в России, так и «против» ее возращения в практику. Выявлена и обоснована невозможность отмены запрета на применение смертной казни иначе как принятием новой Конституции Российской Федерации с положением о безусловном применении смертной казни как вида наказания и механизма его регулирования.

Ключевые слова: смертная казнь, конституционно-правовое регулирование, Конституциионный суд, гуманность, права человека

Проблема смертной казни волновала и будет волновать, как обывателей, так и юристов-практиков, а также государственных деятелей. Всех объединяет одно - неравнодушие и значимость рассматриваемой проблемы смертной казни в России.

Многочисленные требования об отмене моратория на смертную казнь, ведённого еще Борисом Ельциным в 1996 г. и подтвержденного в 2009 г. Конституционным Судом Российской Федерации (далее по тексту - Конституционный Суд РФ) (приговоры не выносятся и не приводятся в исполнение, однако из Уголовного кодекса РФ смертная казнь не исключена), ни один раз появлялись в прессе после различных террористических актов, убийства и истязания детей, а также совершения других не менее чудовищных и зверских преступлений. И в данном случае речь не идет только об эмоциональной составляющей людей, движимых возвращением смертной казни, здесь также, имеет место быть и неверие в справедливость и законность правоохранительной и судебной систем в нашем государстве. Все чаще люди просто требуют выдать им преступника для осуществления само- суда, так как не верят, что законодательство РФ, а также суд смогут назначить справедливое и действительно строгое наказание за совершенные деяния.

Можно сказать, что людьми, требующими отменить мораторий на смертную казнь, движет излишняя жестокость, но та самая жестокость невольно исчезает, когда, например, присяжные выносят свой вердикт, рассматривая тяжкие и особо тяжкие преступления. Так, например, согласно статистическим данным, доля оправдательных приговоров колеблется (17,7\% в 2013 г., $11,3 \%$ в 2015 г., 15,8\% в 2019 г.) и почти в 50-100 раз превышает долю оправданных обычными судьями [1].

Статистика общественного мнения по вопросу допустимости применения смертной казни, по данным опроса фонда «Общественное мнение» (ФОМнибус) показала следующее: $68 \%$ участников опроса считают допустимым применение смертной казни за сексуальное преступление против несовершеннолетних, за убийство (57\%), терроризм (53\%) и изнасилование (52\%). Что касается введенного в России моратория, то поддерживают данный шаг $37 \%$ 
участников опроса, не поддерживают 45\%, 18\% с мнением не определились [2].

Конституцией РФ провозглашается право на жизнь как одно из важнейших прав человека. Так, в соответствии с положениями статьи 20 основного закона Российской Федерации, каждый имеет право на жизнь, а смертная казнь может быть установлена вплоть до ее отмены.

Смертная казнь - это высшая мера уголовного наказания, которая заключается в лишении жизни человека. Как уже упоминалось выше право на жизнь охраняется не только национальным законодательством РФ, но и международными актами, так, например, Протокол № 6 к Конвенции о защите прав человека и основных свобод (Россия данный протокол подписала, но не ратифицировала) предусматривает неприменение смертной казни в мирное время.

В 2009 году Конституционный Суд РФ признал невозможность назначения смертной казни даже после введения суда присяжных в Чечне, обосновав это тем, что «в результате длительного моратория на применение смертной казни сформировались устойчивые гарантии права человека не быть подвергнутым смертной казни, так сложился конституционно-правовой режим, в рамках которого - с учётом международноправовой тенденции и обязательств, взятых на себя Российской Федерацией,- происходит необратимый процесс, направленный на отмену смертной казни, как исключительной меры наказания, носящей временный характер («впредь до её отмены») и допускаемой лишь в течение определённого переходного периода, то есть на реализацию цели, закрепленной статьей 20 (часть 2) Конституции Российской Федерации».

В соответствии со статьей 55 Конституции РФ запрещается отменять или ущемлять права человека, которые гарантируются Конституцией или международно-правовыми нормами, которые стали частью правовой системы Российской Федерации.

С момента вхождения России в Совет Европы возникли проблемы применения смертной казни. Запрет на вынесение смертных приговоров до введения судов присяжных на всей территории России был подтвержден Конституционным Судом РФ в постановлении от 6 апреля 2006 г. № 3-П [3]. Так Конституционный Суд пришел к выводу, что п. 1 Постановления Верховного Совета Российской Федерации от 16 июля 1993 г. больше не может служить основанием для отказа обвиняемому в преступлении, за совершение которого предусматривается наказание в виде смертной казни, в праве на рассмотрение его дела судом с участием присяжных заседателей (п. 6 мотивировочной части). Конституционный Суд установил, что наказание в виде смертной казни на всей территории Российской Федерации может назначаться лишь при предоставлении обвиняемому права на рассмотрение его дела судом с участием присяжных заседателей. Невозможность обеспечить реализацию данного права обвиняемому влечет за собой и невозможность назначения смертной казни иным составом суда. Одновременно в тех субъектах Российской Федерации, где были созданы суды присяжных, обвиняемые в преступлениях, за совершение которых установлена смертная казнь, не должны ставиться в неравноправное положение при определении меры наказания по сравнению с обвиняемыми в таких же преступлениях на территориях, где суд присяжных не функционировал. В данной ситуации применение смертной казни судом с участием присяжных заседателей исказило бы предназначение и существо права, гарантированного ч. 2 ст. 20 Конституции, и явилось бы существенным нарушением принципа равенства, закрепленного ст. 19 Конституции. Поэтому на назначение смертной казни и был наложен запрет.

Приняв Европейскую конвенцию о защите прав и основных свобод, Россия автоматически закрепила за собой обязанность с момента вступления в действие Протокола не применять смертную казнь как вид наказания. Протокол гласит, что «Смертная казнь отменяется. Никто не может быть приговорен к смертной казни» [4]. Кроме того, указанный протокол содержит предписание о том, что наказание в виде смертной казни не может применяться ни при каких условиях, даже при наличии чрезвычайных обстоятельств и ситуаций. Далее, последовал Указ Президента РФ от 16 мая 1996 г. № 724, который вызвал огромный резонанс в Правительстве, в связи с чем в Уголовный Кодекс РФ 1996 г. смертная казнь была оставлена как исключительная мера наказания за определенные виды преступлений.

Таким образом, в соответствии с действующими нормативно правовыми актами во главе с Конституцией смертная казнь, как самое максимальная мера наказания не назначается и не применяется. Во главе этого моратория стоит 
Постановление Конституционного Суда Российской Федерации от 2 февраля 1999 года № 3-П, которое во взаимосвязи с другими его решениями, сформировали некие гарантии прав человека и гражданина, в связи с которыми невозможно быть подвергнутым смертной казни. С учетом международно-правовой тенденции и обязательств, взятых на себя Российской Федерацией,- происходит необратимый процесс, направленный на отмену смертной казни, как исключительной меры наказания, носящей временный характер («впредь до ее отмены») и допускаемой лишь в течение определенного переходного периода, т.е. на реализацию цели, закрепленной статьей 20 (часть 2) Конституции Российской Федерации» [5].

Как верно указывает Т.Г.Морщакова, Конституционным Судом РФ «в принятом Определении был использован не законодательный, а иной, конкурирующий с ним способ отмены смертной казни. Никто не имеет права ни под каким, пусть даже самым добродетельным, предлогом вмешиваться в прерогативы и полномочия другой ветви власти» [6].

Противники применения такого наказания, как смертная казнь считают, что жизнь дарована Богом и никто, даже суд, государство не вправе отнимать ее у человека. Многие авторы в научных кругах придерживаются мнения, что нет нравственного оправдания отнимания жизни у человека, пусть даже признанного виновным.

Осужденный уже не представляет опасности для общества, и необходимо такую жестокую меру наказания исключить из уголовного закона. Приверженцы против смертной казни считают, что ее назначение и исполнение никак не будет способствовать предупреждению совершению новых преступлений, напротив, есть вероятность осуждения или даже убийства невиновного человека.

О.И. Лепешкина считает, что «отмена смертной казни обусловлена официальным признанием приоритета прав человека перед интересами общества и государства» [7]. А. М. Зайцева предположила, что «лишение права на жизнь недопустимо, смертная казнь должна быть отменена» [8]. За отмену смертной казни выступают и другие ученые и практики [9].

Если рассматривать смертную казнь с точки зрения гуманизма, о котором так много твердят противники применения смертной казни, то здесь следует обратиться к положениям УК РФ, в частности к статье 7, согласно которой: «цель наказания не должна заключаться в причинении физических страданий или унижение человеческого достоинства»

Таки образом, если придерживаться принципа гуманизма, то приговор в виде пожизненного лишения свободы вряд ли можно назвать более гуманной мерой наказания нежели смертная казнь. Стоит отметить, что условия содержания заключенных приговоренных к пожизненному лишению свободы за особо тяжкие преступления вряд ли можно назвать «мягкими».

Многие противники смертной казни рассматривают ее с точки зрения архаичного наказания, который может являться средством «избавления от преступников и устрашения населения» [10]. Другими словами, вопрос о полной отмене смертной казни зависит от большого количества факторов, немаловажным из которых является и общественное мнение, которое свидетельствует о том, что обществе еще в недостаточной мере готово к отмене смертной казни в целом [11].

Противники смертной казни в качестве одного из аргументов высказываются о возможности судебной ошибки и тогда возможно будет приговорен к высшей мере невиновный человек. Безусловно, осуществление правосудия невозможно без судебных ошибок. Но, тем не менее, всегда в действующем законодательстве можно предусмотреть особый механизм защиты от таких судебных ошибок, в качестве, которого, например, можно разработать порядок отсрочки исполнения смертной казни.

Но следует отметить, что российская правовая система еще не совсем готова, обеспечить беспристрастное, качественное и справедливое предварительное расследование, а также соответствующее обеспечение рассмотрения уголовного дела в суде, а также гарантировать в процессе осуществления правосудия реализацию института прав человека, в том числе, одного из важнейших его прав, которое гарантировано не только Основным законом РФ, но и Европейской конвенцией, а точнее - само право на жизнь.

Заключение. Несмотря на сотни даже тысячи публикаций, диссертаций и исследований проблемы смертной казни в России, на сегодняшний день, рассматриваемый вопрос так и остается открытым.

Рассмотрев позиции как «за» применение в качестве высшей меры наказания - смертную 
казнь в России, так и позиции «против», можно прийти к следующим выводам:

Нет сомнений в том, что право на жизнь является неотъемлемым правом каждого человека с рождения, и даже преступника, на счету которого ни одно тяжкое и особо тяжкое преступление. Но это право имеют и те, кто был, например, невинно убит этим же преступником. И когда, действительно, речь идет о наказании за такие преступления как убийство детей, терроризм и других не менее жесточайших преступлениях против человечества и государства, невольно задумываешься о необходимости отмены введенного моратория на смертную казнь. Опять же если говорить о гуманном отношении к заключенным, то осуждение к пожизненному лишению свободы ничуть не гуманнее смертной казни.

С введением моратория на смертную казнь, вопрос «быть или не быть смертной казни» ни раз поднимался, поднимается и будет обсуждаться в связи с неоднородностью нормативных актов, регулирующих данный вопрос. С возобновлением обсуждения вопроса о возвращении смертной казни депутатами Государственной Думы, встает вопрос о нормативном регулировании в системе конституционного права Российской Федерации, в частности, в соотношении актов высших органов власти между собой. С одной стороны, Федеральное Собрание не может преодолеть решение Конституционного Суда законотворческой деятельностью, с другой стороны, депутаты уполномочены вносить изменения в действующие нормативно-правовые акты, регулирующие порядок функционирования самого Конституционного Суда, включая (но при этом не ограничиваясь), нормативную силу его решений. Также, стоит отметить, что в соответствии с положениями статьи 135 Конституции РФ, парламентарии имеют возможность инициировать пересмотр действующей Конституции в части регулирования права на жизнь путем созыва Конституционного Собрания и разработки проекта новой Конституции Российской Федерации с вынесением последнего на всенародное голосование. В связи с вышеизложенным, можно привести мнение Тамары Морщаковой (Заместителя Председателя Конституционного Суда Российской Федерации (в отставке), которая считает, что вернуть в Россию смертную казнь невозможно. Единственный способ - принять новую Конституцию [12].

К сожалению, приходится констатировать, что в России до сих пор не поставлена точка в споре, имеет ли место быть смертная казнь или нет. На сегодняшний день так и действует принцип «ни отмены, ни применения», что может, в конечном счете негативно сказаться на регулятивной функции права.

\section{Библиографический список}

1. Почему в России нельзя отменить смертную казнь // Ведомости.- Электронный pecypc] https://www. vedomosti.ru/opinion/articles/2019/10/13/813580-moratorii-smertnuyu-kazn

2. Официальный сайт ФОМнибус [Электронный ресурс]. URL: https: // ria.ru / organization _ FOMnibus/.

3. По делу о проверке конституционности отдельных положений Федерального конституционного закона «О военных судах Российской Федерации», Федеральных законов «О присяжных заседателях федеральных судов общей юрисдикции в Российской Федерации», «О введении в действие Уголовно-процессуального кодекса Российской Федерации» и Уголовно-процессуального кодекса Российской Федерации в связи с запросом Президента Чеченской Республики, жалобой гражданки К.Г.Тубуровой и запросом СевероКавказского окружного военного суда: Постановление Конституционного Суда РФ от 06.04.2006 № 3-П [Электронный ресурс]. Доступ из справ.-правовой системы «КонсультантПлюс»

4. Протокол № 6 к Конвенции о защите прав человека и основных свобод относительно отмены смертной казни (Страсбург, 28 апреля 1983 г.) // Действующее международное право. М., 1997. Т.2.

5. О разъяснении пункта 5 резолютивной части Постановления Конституционного Суда Российской Федерации от 2 февраля 1999 года № 3-П по делу о проверке конституционности положений статьи 41 и части третьей статьи 42 Уголовно-процессуального кодекса РСФСР, пунктов 1 и 2 Постановления Верховного Совета Российской Федерации от 16 июля 1993 года «О порядке введения в действие Закона Российской Федерации «О внесении изменений и дополнений в Закон РСФСР «О судоустройстве РСФСР», Уголовнопроцессуальный кодекс РСФСР, Уголовный кодекс РСФСР и Кодекс РСФСР об административных правонарушениях: Определение Конституционного Суда РФ от 19.11.2009 N 1344-О-Р [Электронный ресурс]. Доступ из справ.-правовой системы «КонсультантПлюс»

6. Морщакова Т.Г. И суда нет. Диагноз доктора Морщаковой // Новая газета. 2004. № 7. С. 45. 
7. Лепешкина О.И. К вопросу о возможности применения смертной казни в России // Рос. юстиция. 2009. № 9. C. 51.

8. Зайцева А.М. Пределы ограничения права на жизнь // Конституционное и муниципальное право. 2008. № 18. C. 25.

9. Квашис В.Е. Смертная казнь. Мировые тенденции, проблемы и перспективы. М., 2008. 609 с.

10. Лепешкина О.И. К вопросу о возможности применения смертной казни в России // Российская юстиция. 2009. № 9. С. $48-49$.

11. Борисов А.В. Уголовно-правовые и специально-криминологические меры борьбы с нарушениями авторского и патентного права. Диссертация на соискание ученой степени кандидата юридических наук / Академия экономической безопасности Министерства внутренних дел Российской Федерации. Москва, 2008. $156 \mathrm{c.}$

12. Морщакова Т.Г. Правовая легализация отмены смертной казни в России // Сравнительное конституционное обозрение. 2010. № 1. С. 185-187. 